\section{ISSUES AFFECTING}

WATER QUALITY

Surface-water and ground-water quality and aquatic life can be significantly affected by the following principal issues identified in the AlleghenyMonongahela River Basin:

- Contaminants common to surface and underground coal mine discharge such as acidity, iron, aluminum, manganese, and sulfate.

- Volatile organic compounds (VOC's), pesticides, and nutrients from increased urbanization.

- Runoff and loading of nutrients and pesticides to streams from nonpoint and point sources such as agricultural land uses.

- Radon in ground water.

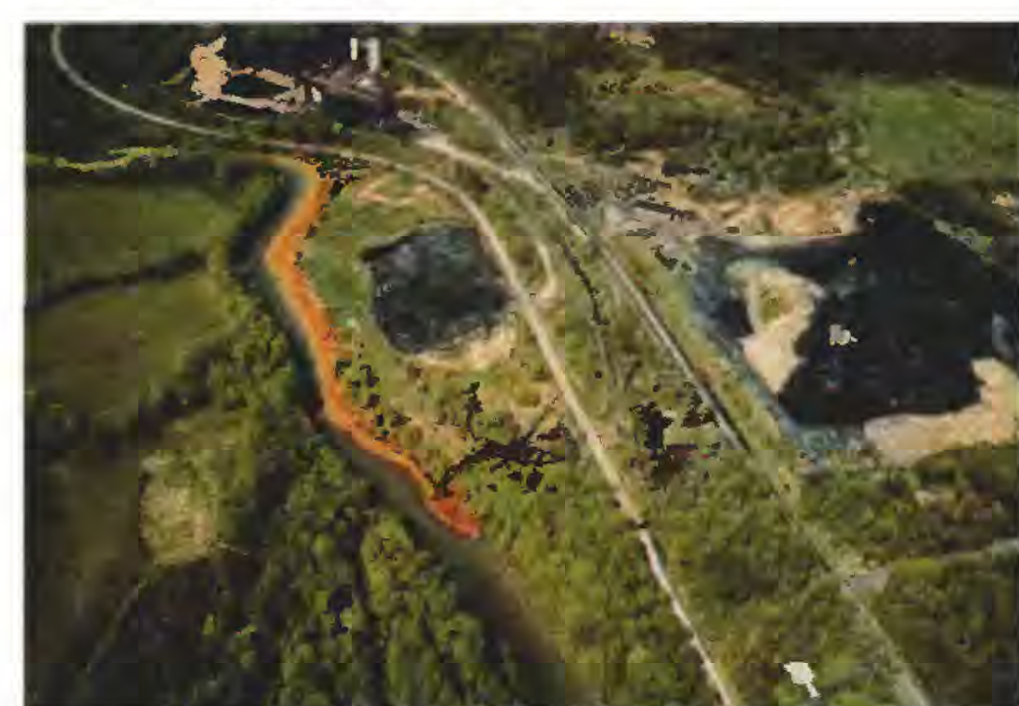

Effects of mining in Stonycreek Basin

\section{COMMUNICATION}

AND COORDINATION

Communication and coordination between USGS personnel and other interested scientists and watermanagement organizations are important components of the NAWQA Program. The liaison committee for the Allegheny-Monongahela River Basin study unit has proved very effective in the communication and coordination processes. The committee consists of representatives from Federal, State, and local agencies, universities, and the private sector, all of whom have water-resource responsibilities and interests.

\section{IMPLEMENTATION}

Initial project activities included detailed planning during the first year and analysis of existing data during the second year. The succeeding 3 years are for intensive data collection and analysis. The sixth year is for completion of data analysis and reports. These activities will be followed by a period of low-level assessment, mainly intermittent water-quality monitoring at selected sites.

\begin{tabular}{|c|c|c|c|c|c|c|c|c|c|c|}
\hline ACTIVITIES & 奇 & 访 & \%̆ & 曽 & 罟 & 兽 & ఫ్ & ڤ్ & ণั้ & ڤ్ \\
\hline PLANNING & & & & & & & & & & \\
\hline $\begin{array}{l}\text { ANALYSIS OF } \\
\text { EXISTING DATA }\end{array}$ & & & & & & & & & & \\
\hline $\begin{array}{l}\text { DATA COLLECTION } \\
\text { AND ANALYSIS }\end{array}$ & & & & & & & & & & \\
\hline $\begin{array}{l}\text { COMPLETION OF } \\
\text { ANALYSIS AND REPORTS }\end{array}$ & & & & & & & & & & \\
\hline $\begin{array}{l}\text { LOW-LEVEL } \\
\text { ASSESSMENT }\end{array}$ & & & & & & & & & & \\
\hline
\end{tabular}

\section{FOR INFORMATION}

Information on technical reports and hydrologic data related to the Allegheny-Monongahela River Basin NAWQA study can be obtained from:

Project Chief

Allegheny-Monongahela River Basin NAWQA

U.S. Geological Survey, Water Resource Division at

1000 Liberty Avenue, Rm. 2204

Pittsburgh, PA 15222

or

840 Market Street

Lemoyne, PA 17043

Telephone: (412) 644-2707

Fax: (412) 355-2548

http://wwwpah2o.er.usgs.gov/

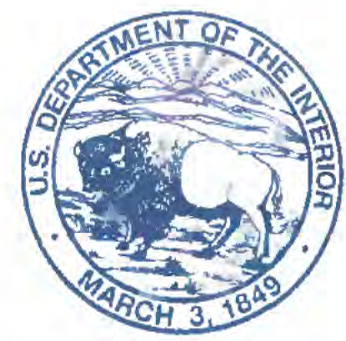

July 1997

Steven D. McAuley, Juliane B. Brown and James I. Sams, III

\section{NAWQA}

\section{National Water-Quality Assessment Program} Allegheny-Monongahela River Basin

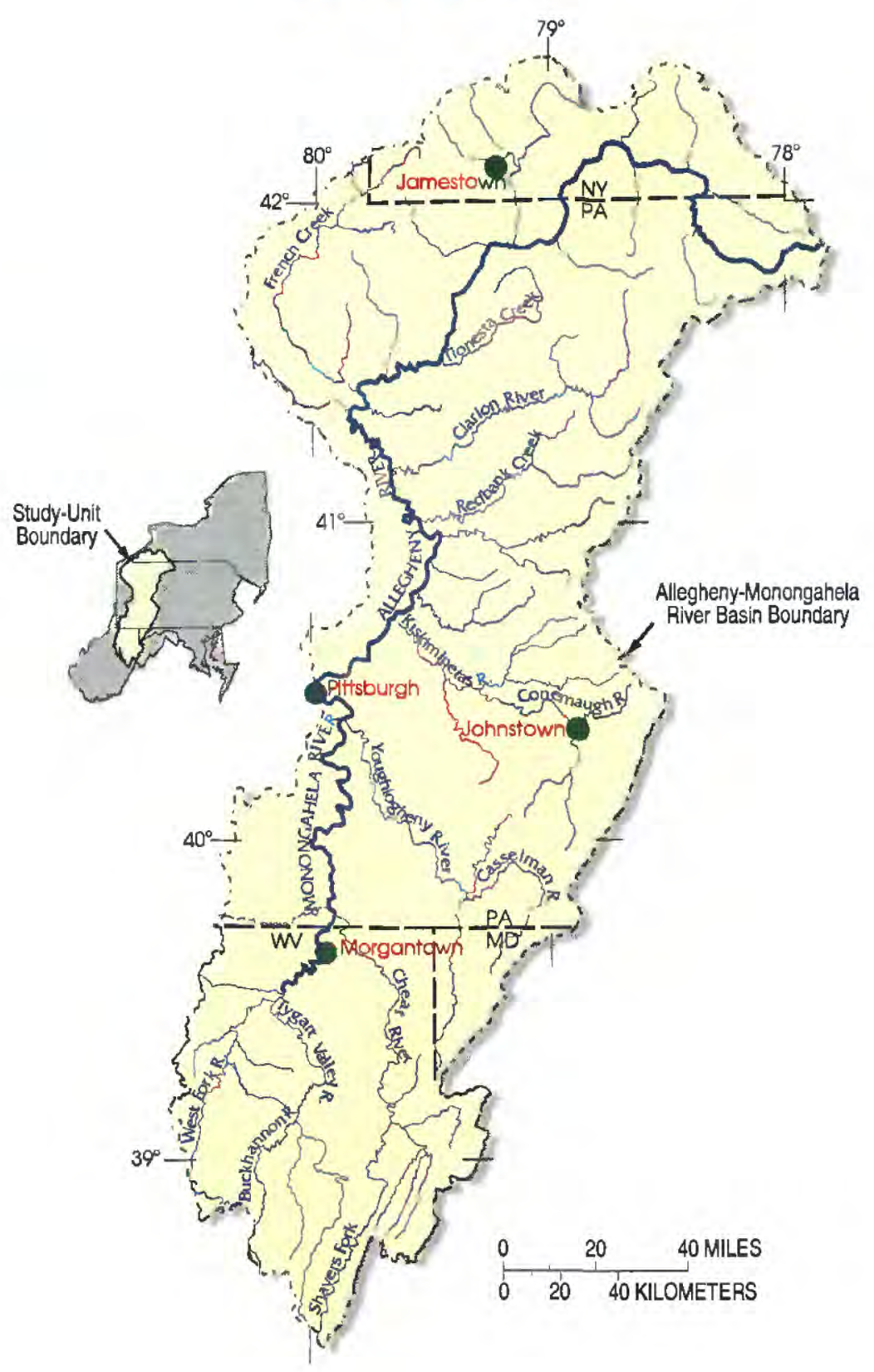




\section{GOALS OF NAWQA}

The protection and enhancement of the quality of the Nation's ground-water and surface-water resources are high-priority concerns to the public. Nationally consistent information on the status and trends of the Nation's water quality is needed to help determine the effectiveness of past water-quality programs and to provide a base of knowledge for making future watermanagement decisions. The U.S. Geological Survey's (USGS) National Water-Quality Assessment (NAWQA) Program was developed to meet these needs.

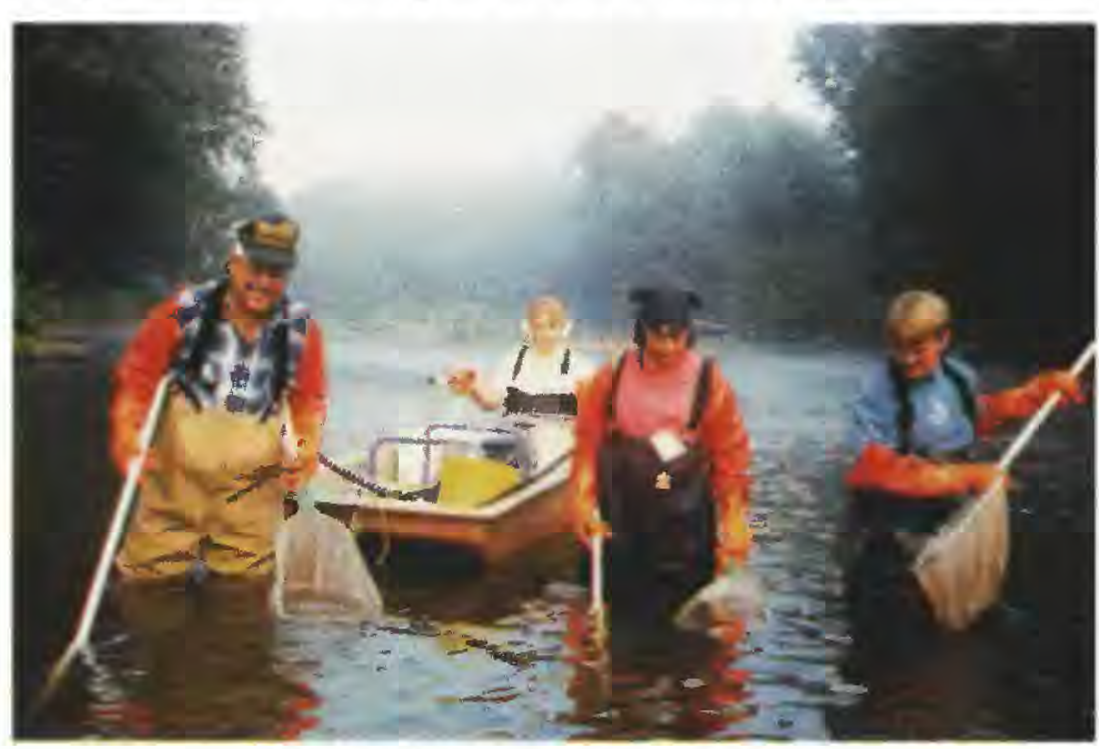

Electrofishing on French Creek

The NAWQA Program is designed to use a multiscale, integrated, and interdisciplinary approach to waterquality assessment. With information provided by local water managers and water users in each basin and knowledge gained from reviewing all of the historic data, data-collection networks are developed by the USGS to examine the physical, chemical, and biological aspects of the basin. Results from this effort enable the USGS to meet its program goals by describing current water-quality conditions and identifying natural and human factors affecting basin water quality.

\section{DESIGN OF NAWQA}

Studies of the hydrologic systems that include parts of most major river basins and aquifer systems (study-unit investigations) are the building blocks of the NAWQA Program. Approximately 60 study units selected for investigation range in size from less than 1,000 to more

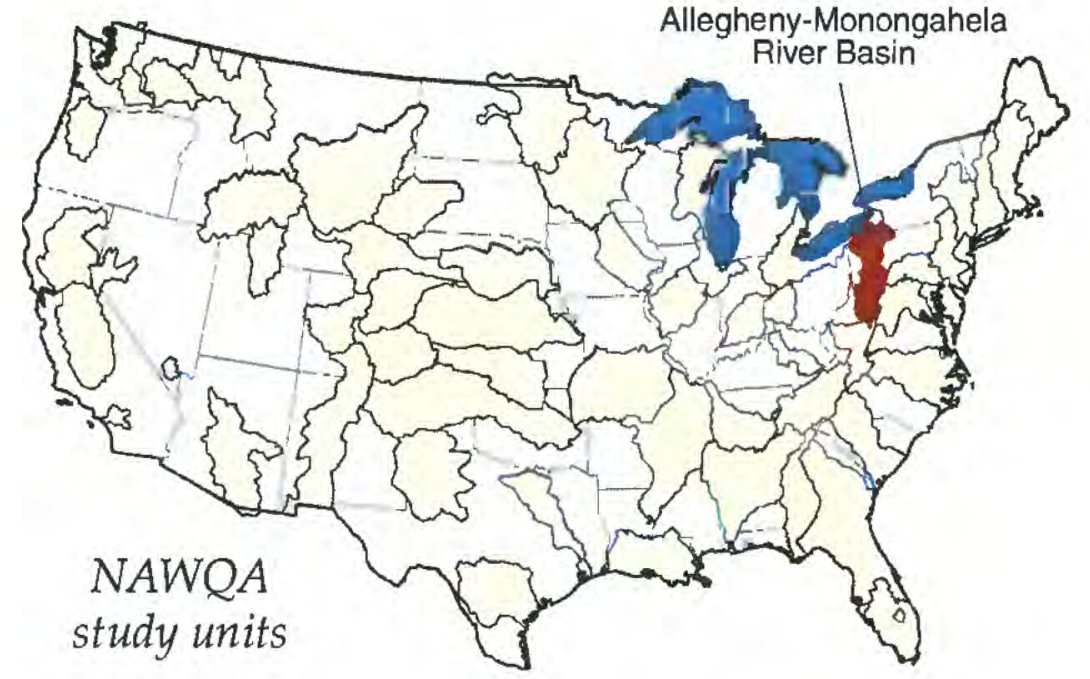

than 60,000 square miles and represent 60 to 70 percent of the Nation's water use and population served by public water supplies. Twenty study-unit investigations were started in 1991, and an additional 16 were started in 1994 (of which the Allegheny-Monongahela River Basin is one), and 20 more are planned to start in 1997.

\section{DESCRIPTION OF THE
ALLEGHENY-MONONGAHELA
RIVER BASIN STUDY UNIT}

- The total combined drainage area of the Allegheny River and the Monongahela River Basins is 19,145 square miles.

- Average annual precipitation for the study unit is 42 inches and ranges from 37 inches in northern areas to 60 inches in the southern, mountainous areas.

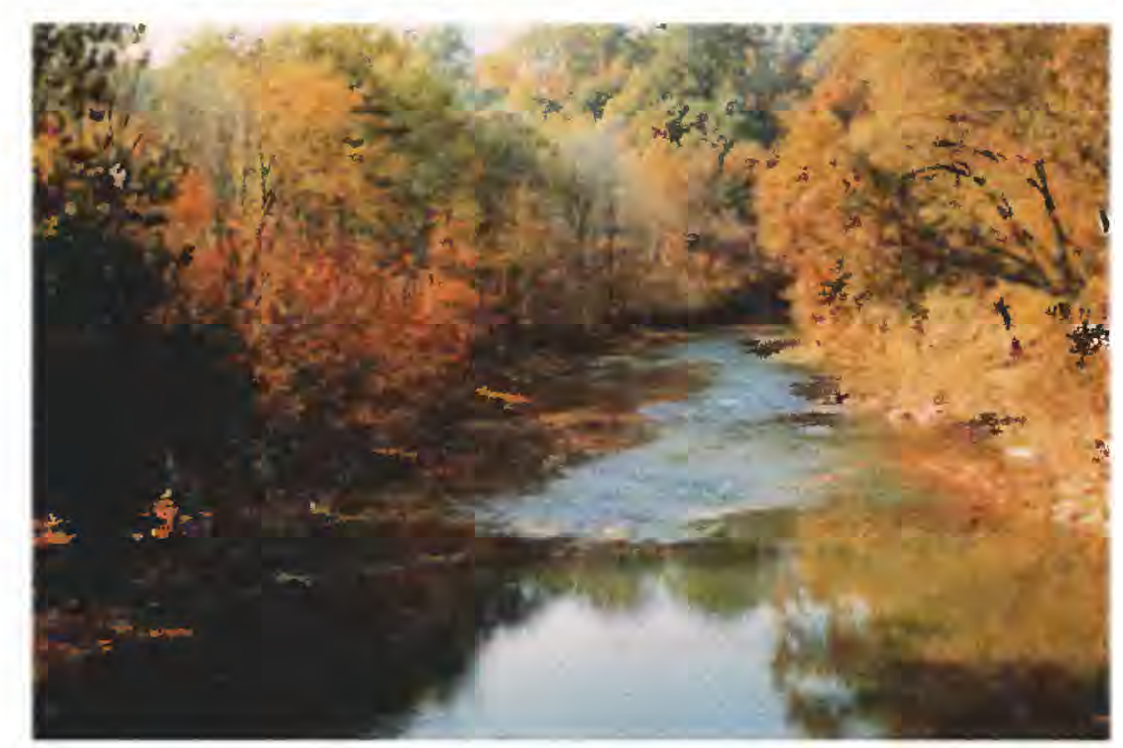

Dunkard Creek
- Average annual runoff to streams ranges from 25 to 40 inches per year in the mountainous southeastern areas and from 18 to 26 inches elsewhere. Average annual recharge to the ground-water system is estimated to range from 8 to 15 inches.

- In 1990, water withdrawn from aquifers and surface-water bodies in the study unit averaged 3 billion gallons per day, most of which was from surface-water sources.

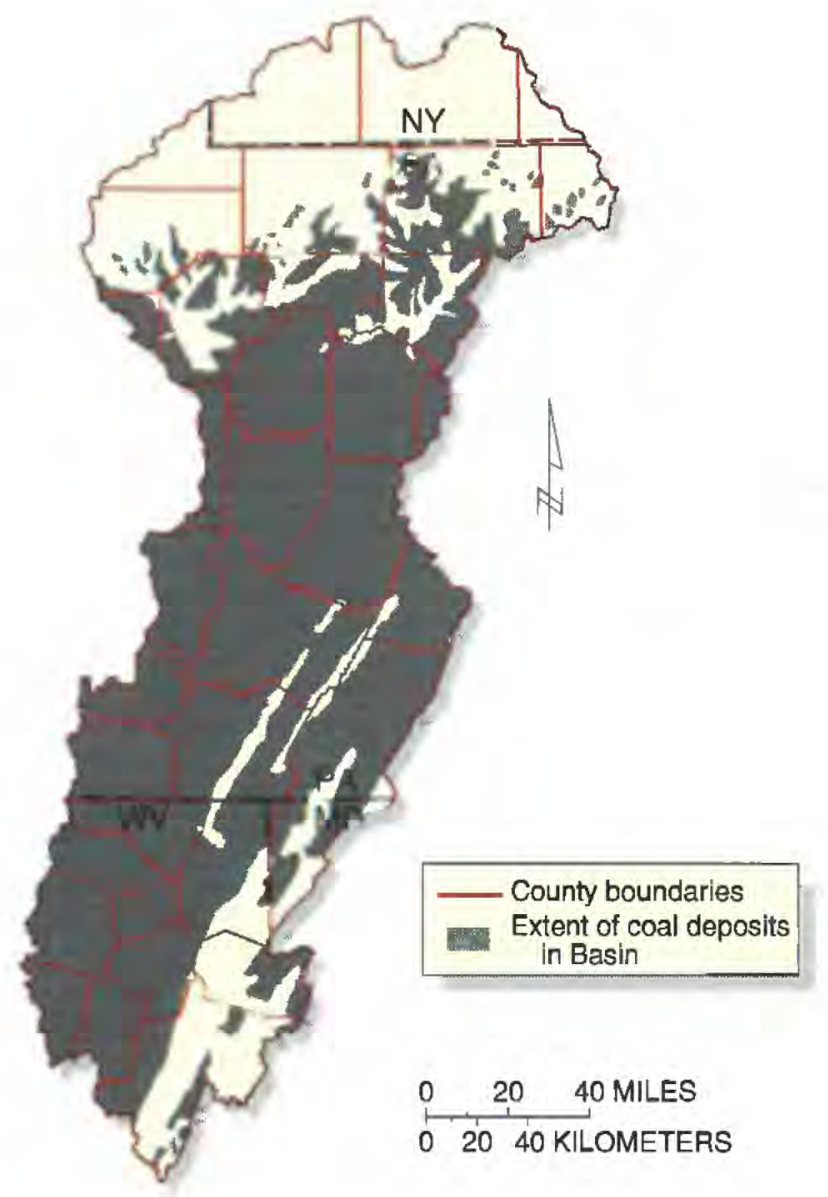

- Major industries include coal mining, manufacturing, oil and gas production, construction activities, transportation-related projects, forestry, agriculture, and outdoor recreation.

- Approximately 3,122,000 people lived within the study unit, according to 1990 U.S. Census Bureau population data.

- 1970 land-use data indicated forest land as 64 percent, agricultural land as 30 percent, urban land as 4 percent, barren or unvegetated mined land as 1 percent, and 1 percent of the basin as streams, lakes, and wetlands. 